\title{
Resource Use Efficiency of Swarna and Swarna Sub1 Rice Variety Cultivation in Chandauli District of Uttar Pradesh, India
}

\author{
Amita Maurya $^{1^{*}}$ and H.N. Singh ${ }^{2}$ \\ ${ }^{1}$ Departmentof Agricultural Economics, Institute of Agricultural Sciences, B.H.U., India \\ ${ }^{2}$ Department of Agril. Economics, college of agriculture, G.B.P.U.A.T., Pantnagar, India \\ *Corresponding author
}

\section{A B S T R A C T}

\section{Keywords}

Rice, Irrigated uplands, Rainfed lowland, Deep water

Article Info

Accepted:

18 August 2018

Available Online:

10 September 2018
The attempt was made in the study to examine the economics of cultivation of Swarna subl rice in Chandauli district of Uttar Pradesh. 60 farmers were surveyed on the basis of those who cultivated swarna subl. Efficiency of resources in swarna subl and swarna cultivation was examined through Cobb-Douglas production function and MVP analysis. It was found that there was no multicollinearity between any pair of explanatory variables in both varieties. The coefficient of multiple determinations $\left(\mathrm{R}^{2}\right)$ was found to be 0.69 and 0.63 for swarna $s u b 1$ and swarna, respectively. In case of swarna $s u b 1$ variety fertilizer and machine labour and in case of swarna seed, fertilizer, plant protection chemical, hired labour and machine labour were found to be statistically significant that these inputs are not optimally utilized by the farmers. There is need to disseminate modern technology employing extension services of government programmes and to strengthen farmer's knowledge through better extension services and training so that they can apply available agricultural resources more efficiently in stress prone areas.

\section{Introduction}

Rice is grown in a great range of ecologies ranging from irrigated uplands to rainfed lowland, deep water and tidal wetlands. About $29 \%$ of India's total rice area, i.e. $13 \mathrm{~m}$ ha is rainfed lowland, which contributes only 19\% to national rice production. In a normal year, about $4 \mathrm{~m}$ ha is drought-prone, while $3 \mathrm{~m}$ ha is favourable, another $3 \mathrm{~m}$ ha is medium deep waterlogged with water standing for up to 50 $\mathrm{cm}$. The remaining $3 \mathrm{~m}$ ha is submergence or flood-prone, where plants are completely submerged for 1-2 weeks or so, resulting in partial or even complete crop failure. Rainfed lowlands constitute highly fragile ecosystems, always prone to flash-floods (submergence) with an average productivity of only $1.2 \mathrm{t} / \mathrm{ha}$ in normal years and hardly $0.5 \mathrm{t} /$ ha in case of submergence. Among the 42 biotic and abiotic stresses affecting rice production, submergence has been identified as the third most important constraint for higher rice productivity in eastern India after drought and weeds, because it sometimes resulted in near total yield loss. The main constraint is a lack of suitable high yielding varieties that can tolerate complete submergence and have good grain quality. Indian cultivar 'FR13A' is the most widely studied variety and it is used as a 
source of submergence tolerance in rice breeding. A major quantitative trait locus, designated Subl, was identified that controls most of the submergence tolerance of this genotype (Xu and Mackill, 1996). On the other hand, Swarna, a popular rainfed lowland Indian variety having high yield, adaptation to low input, moderate tolerance to various stresses and good grain qualities, the bond between farmers and swarna in the parlance of agricultural scientists seems to be eternal.

The popularity of swarna provided an opportunity to use it to dispatch important gene like subl to farmers. Farmers facing the submergence problem have the risk of uncertainties in rice production and due to this, they use little inputs also, now the problem is how efficiently they use the inputs. To overcome the problem of yield losses in rice due to submergence in lowland areas subl gene varieties may be instrumented with the view of above, the estimation of resource use efficiency of swarna subl and swarna has been taken for study.

\section{Materials and Methods}

The study was done in Chandauli district of Uttar Pradesh and mainly based on primary data. The required primary data were collected personally by survey method and secondary data were collected from various published records of government offices, books, block development offices, reports, and other related sources. The district comprises of nine development blocks, viz. Barahani, Chandauli, Niyamtabad, Chahaniya, Sakaldeeha, Dhanapur, Chakiya, Shahabganj and Naugarh. The selection of farmers is targeted to those farmers who grow Swarna sub1 rice variety on their farms. The survey year was the beginning of initiation of Swarna Subl cultivation in the area after its release from CVRC. Therefore, scanty nature of farmers over large number of villages was available for this study. A sample of 60 farmers belongs to 15 different villages of Chandauli block selected for detail study. Census method was followed for data collection for the study. To evaluate the resource use efficiency and estimate the marginal productivity, production function analysis was used. The functional relationship of Cobb-Douglas function for the study is specified as follows.

$\mathrm{Y}=\mathrm{a} \mathrm{X}_{1}{ }^{\mathrm{b} 1} \mathrm{X}_{2}{ }^{\mathrm{b} 2} \mathrm{X}_{3}{ }^{\mathrm{b} 3} \mathrm{X}_{4}^{\mathrm{b} 4} \mathrm{X}_{5}^{\mathrm{b} 5} \mathrm{X}_{6}^{\mathrm{b} 6} \mathrm{e}^{\mathrm{u}}$

Where,

$\mathrm{Y}=$ Rice yield (qtl /ha.)

$\mathrm{X}_{1}=$ Seed quantity in $\mathrm{kg} / \mathrm{ha}$.

$\mathrm{X}_{2}=$ manure fertilizers (Rs. / hectare).

$\mathrm{X}_{3}=$ plant protection in (Rs. / hectare).

$\mathrm{X}_{4}=$ Human labour (men /ha.).

$\mathrm{X}_{5}=$ Expenditure on machine or bullock labour (hours /day).

$\mathrm{X}_{6}=$ Irrigation (Rs./ha).

$\mathrm{U}=$ Error term

$\mathrm{a}=$ constant

$\mathrm{e}=$ Napier base

$b_{1} \cdot b_{6}=$ Régression coefficient

\section{Estimation procedure}

The Ordinary least square (OLS method) is to be used for estimating the parameters associated with different independent variables. This function is expressed in the linear form as-

$\ln \mathrm{Y}=\ln \mathrm{a}+\mathrm{b}_{1} \ln \mathrm{X}_{1}+\ldots \ldots . .+\mathrm{b}_{\mathrm{n}} \ln \mathrm{X}_{\mathrm{n}}+\mathrm{U}$ 
The estimable form of the function is formally expressed as-

$y=a+b_{1} x_{1}+\ldots \ldots+b_{n} x_{n}+U$

Where,

$y=\ln Y ; x j=\ln X_{j}$ for $j=1$ to $n ; a=\ln a ; \ln =$ Natural logarithm

Estimation of marginal productivity of factors

Estimate of the parameters $\beta_{1} \ldots \beta_{\mathrm{n}}$ are elasticities of $Y$ with respect to $j^{\text {th }}$ input. The marginal products of the resources will be derived from these elasticity coefficients.

The marginal value products of significant inputs will be worked out at its geometric mean level by using the formula

$\mathrm{MVP}_{j}=b_{j} \frac{\overline{\mathrm{Y}}}{\overline{\mathrm{X}}_{\mathrm{j}}} . \mathrm{Py}$

Where

$\mathrm{MVP}_{\mathrm{j}}$ - Marginal value product of jth product

Y - Geometric mean level of output

$\bar{X}$ - Geometric mean of input ' $\mathrm{j}$ '

$b_{j}$ - Estimated co-efficient of elasticities

Py - Price per unit output

Marginal Value Product (MVP) of each input is compared with Marginal Input Cost (MIC) in order to estimate the efficiency.

Economic rationale of resource use was examined by comparing marginal value product of a given resource with the marginal input cost (allocative efficiency).
$\mathrm{AE}_{\mathrm{xi}}=\mathrm{MVP}_{\mathrm{Xi}} / \mathrm{MIC}_{\mathrm{Xi}}$

Where;

$A E_{x i}=$ allocative efficiency of $i^{\text {th }}$ input

$\mathrm{MVP}_{\mathrm{xi}}=$ marginal value product of $\mathrm{i}^{\text {th }}$ input

$\mathrm{MIC}_{\mathrm{xi}}=$ marginal input cost of $\mathrm{i}^{\text {th }}$ input

If the marginal value product of $i^{\text {th }}$ input is greater or less than the marginal input cost of $i^{\text {th }}$ input, it is said that the resource is not use optimally. For optimal use of an $i^{\text {th }}$ resource the marginal value product of the ith input/resource should equal to marginal input cost of the $i^{\text {th }}$ input/resource.

\section{Results and Discussion}

An understanding of the average output response to the change in inputs is useful to know the resource use efficiency of different inputs used in crop production. Cobb-Douglas production function was employed to compute the production elasticity of different inputs due to its several inherent advantage and ordinary least squares(OLS) procedure was used for estimation of function. Production function was fitted separately for all the farms for swarna subl and swarna. The input variables included in the production function were seed (kg/ha), fertilizers (Rs./ha), labour measured in man days/ha, machine use was measured in Rs./ha, irrigation charges and plant protection chemical measured in Rs./ ha.

Prior to the estimation of regression equation, zero order correlation matrices were estimated with the view to examine the degree as well as the kind of association among the variables considered in regression analysis. This was also required in order to examine the presence of multicollinearity between different pairs of independent variables and to take necessary steps to get rid of problem. 
Resource use efficiency in Swarna sub1 variety

The coefficient of multiple determinations $\left(R^{2}\right)$ was 0.69 , indicating that the variables included in the function could explain $69 \%$ variation in yield of Swarna subl variety. In production function, the coefficient of input variables is representing the production elasticity of the resources used. The coefficient of variables such as fertilizer and machine labour were significant with the values 0.291 and 0.230 implying that $1 \%$ increase in the above said variables from the existing mean level would increase the swarna subl rice yield by 0.291 and $0.230 \%$ respectively. The coefficient of variables such as seeds, plant protection chemicals, human labour and irrigation charges were found to be non-significant.

The difference between marginal value products (MVPs) of the variables to their respective marginal input cost (MICs) was found to be statistically significant among resources such as fertilizer and machine labour. The significant deviation from optimality is the indication of resource inefficiency of the aforesaid inputs. From the existing situation it was suggested to increase the level of resource use of aforesaid inputs in order to increase the swarna subl yield.

\section{Estimated resource use efficiency in Swarna sub1 variety}

\begin{tabular}{|l|l|l|l|l|l|}
\hline variable & Coefficients & S.E & MVP & MIC & MVP/MIC \\
\hline Intercept & 4.502 & 2.067 & - & - & - \\
\hline Seed & 0.073 & 0.083 & 29884.390 & 3000.000 & 9.131 \\
\hline Fertilizer & $0.291^{*}$ & 0.057 & 331.109 & 1.000 & 303.517 \\
\hline Plant protection chemicals & 0.033 & 0.220 & 118.163 & 1.000 & 108.316 \\
\hline Human labour & 0.005 & 0.048 & 266.207 & 150.000 & 1.626 \\
\hline Machine labour & $0.230^{* *}$ & 0.093 & 435.446 & 1.000 & 399.158 \\
\hline Irrigation & -0.104 & 0.119 & -269.040 & 1.000 & -246.620 \\
\hline
\end{tabular}

***,** and * indicates level of significance at 1,5 and $10 \%$ probability level, $\mathrm{R}^{2}-0.69$

Estimated resource use efficiency in Swarna variety

\begin{tabular}{|l|l|l|l|l|l|}
\hline variable & Coefficients & S.E & MVP & MIC & MVP/MIC \\
\hline Intercept & 18.160 & 13.605 & - & - & - \\
\hline Seed & $-0.232^{*}$ & 0.067 & -77189.400 & 3400.000 & -22.700 \\
\hline Fertilize & $-3.821^{*}$ & 1.419 & -3525.900 & 1.000 & -3525.900 \\
\hline Plant protection chemicals & $3.859^{*}$ & 0.781 & 14010.480 & 1.000 & 14010.480 \\
\hline Human labour & $0.509^{* *}$ & 0.227 & 21577.000 & 150.000 & 143.846 \\
\hline Machine labour & $0.223^{* * *}$ & 0.125 & 408.926 & 1.000 & 408.926 \\
\hline Irrigation & 0.007 & 0.018 & 58.010 & 1.000 & 58.010
\end{tabular}

$* * *, * *$ and $*$ indicates level of significance at 1,5 and $10 \%$ probability level, $\mathrm{R}^{2}-0.63$

\section{Resource use efficiency in Swarna variety}

The coefficient of multiple determination $\left(\mathrm{R}^{2}\right)$ was 0.63 , indicating that the variables included in the function could explain $63 \%$ variation in yield of swarna rice variety and rest by the error term. The value of regression coefficient for seed, fertilizer, plant protection 
\& chemical, hired labour and machine labour were noted to be $-0.232,-3.821,3.859,0.509$ and 0.223 , respectively showing that one $\%$ change from the existing mean level of the aforesaid variables would change the rice yield respectively by $-0.232,-3.821,3.859$, 0.509 and $0.223 \%$, which means $1.00 \mathrm{~kg}$ increase in seed, decreases rice yield by $0.23 \mathrm{~kg}$ per hectare. In case of fertilizer, increase in cost of fertilizer Rs. 1.00 per hectare reduces rice yield by $3.82 \mathrm{~kg}$ per hectare. Whereas, increase in cost of plant protection \& chemical by Rs. 1.00 per hectare increases rice yield by $3.85 \mathrm{~kg}$ per hectare.

Similarly increase in one unit labour days increases rice yield by $0.50 \mathrm{~kg}$ per hectare and 1.00 rupee increase in cost of machine labour per hectare, increases rice yield by $0.22 \mathrm{~kg}$ per hectare.

The difference between MVPs and MICs of inputs such as seed, fertilizer, plant protection chemical, hired labour and machine labour were found to be statistically significant that these inputs are not optimally utilized by the farmers.

The Cobb-Douglas production function was fitted and the difference between MVPs to the inputs to their respective prices was calculated to examine the efficiency of resource use in swarna subl and swarna rice varieties cultivation. It was found that there was no multicollinearity between any pair of explainatory variables in both varieties. The coefficient of multiple determinations $\left(\mathrm{R}^{2}\right)$ was found to be 0.69 and 0.63 for swarna subl and swarna, respectively. The difference between marginal value products (MVPs) of the variables to their respective marginal input cost (MICs) was found to be statistically significant among resources such as fertilizer and machine labour in case of swarna subl and seed, fertilizer, plant protection chemical, hired labour and machine labour in case of swarna were found statistically significant. This results indicating that these inputs are not optimally utilized by the farmers. From existing situation it was suggested to increase the level of resources use in order to increase the yield of swarna subl and swarna which ultimately enhances income of rice growers in the region.

\section{Policy implications}

The resources such as fertilizer and machine labour were found to be utilized under the optimum level by the farmers for growing swarna subl. In swarna cultivation seed, fertilizer, plant protection chemical, hired labour and machine labour were the resources found to be under-utilized by the farmers and their level could be increased in order to increase the yield level of rice. In both the varieties fertilizer and machine labour were underutilized by the farmers. It could be suggested that through effective extension activities and policies related to subsidies on fertilizers and discount in rate of interest of machine should be provide to increase the fertilizer and machine labour use with a view to enhance the rice yield level.

\section{References}

Badal, P. S. and Singh, R. P. 2001. Technological change in maize production: A case study of Bihar. Indian Journal of Agricultural Economics, 56(2): 211-219.

Majumder. M. K, Mozumdar. L and Roy. P. C. 2009. "Productivity and Resource Use Efficiency of Boro Rice Production", J. Bangladesh Agril. Univ. 7(2): 247-252

Muralidharan. P. K. 1987. "Resource use efficiency in kole lands in Trichur District, Kerala". Indian Journal of Agricultural Economics, 42(4): 578-586 
Olaqoke, M.A. 1990. 'Efficiency of resource use in ice production system in Anambra state, Nigera'. African Rural Social Sciences Series, 7, 6-24.

Senthilkumar. C and Alagumani. T. 2005. "Resource Use Efficiency of Paddy in Lower Bhavani Project Command Area in Tamil Nadu", Indian Journal of
Agricultural Economics, 60(3): 515516.

Sunandini, G.P., Shaik, H., Rao, R.C.A. and Reddy, Y.V.R. 1993. 'Resource productivity and resource use efficiency on paddy farms of Andhra Pradesh'. Agricultural situation in India. 47(11):92-93.

\section{How to cite this article:}

Amita Maurya and Singh, H.N. 2018. Resource Use Efficiency of Swarna and Swarna Sub1 Rice Variety Cultivation in Chandauli District of Uttar Pradesh, India. Int.J.Curr.Microbiol.App.Sci. 7(09): 2552-2557. doi: https://doi.org/10.20546/ijcmas.2018.709.317 